\title{
Author Correction: Evidence for SARS-CoV-2 related coronaviruses circulating in bats and pangolins in Southeast Asia
}

Supaporn Wacharapluesadee, Chee Wah Tan (D), Patarapol Maneeorn, Prateep Duengkae, Feng Zhu (D),

Yutthana Joyjinda, Thongchai Kaewpom, Wan Ni Chia, Weenassarin Ampoot, Beng Lee Lim,

Kanthita Worachotsueptrakun, Vivian Chih-Wei Chen (1), Nutthinee Sirichan, Chanida Ruchisrisarod,

Apaporn Rodpan, Kirana Noradechanon, Thanawadee Phaichana, Niran Jantarat, Boonchu Thongnumchaima,

Changchun Tu (D), Gary Crameri, Martha M. Stokes, Thiravat Hemachudha \& Lin-Fa Wang (D)

Correction to: Nature Communications https://doi.org/10.1038/s41467-021-21240-1, published online 09 February 2021.

The original version of this Article contained an error in the author affiliation.

Lin-Fa Wang was incorrectly associated with Thai Red Cross Emerging Infectious Diseases Health Science Centre, WHO Collaborating Centre for Research and Training on Viral Zoonoses, King Chulalongkorn Memorial Hospital, Faculty of Medicine, Chulalongkorn University, Bangkok, Thailand.

This has now been corrected in both the PDF and HTML versions of the Article.

Published online: 25 February 2021

\footnotetext{
(c) Open Access This article is licensed under a Creative Commons Attribution 4.0 International License, which permits use, sharing, adaptation, distribution and reproduction in any medium or format, as long as you give appropriate credit to the original author(s) and the source, provide a link to the Creative Commons license, and indicate if changes were made. The images or other third party material in this article are included in the article's Creative Commons license, unless indicated otherwise in a credit line to the material. If material is not included in the article's Creative Commons license and your intended use is not permitted by statutory regulation or exceeds the permitted use, you will need to obtain permission directly from the copyright holder. To view a copy of this license, visit http://creativecommons.org/licenses/by/4.0/.
}

(C) The Author(s) 2021 